Onkologie 1991;14:2-4

\title{
Inhalt, Vol. 14, No. 1, 1991
}

\section{Contents}

\section{Editorial}

ONKOLOGIE - Warum eine Internationale Zeitschrift?

Queißer, W

Editorial ONKOLOGIE - Why an International Magazine?

Queißer, W

Übersichtsarbeiten

Vinorelbin (Navelbine $\left.{ }^{\circledR}\right)$, ein neues semisynthetisches Vincaalkaloid*

Krikorian, A., Breillout, F

Review Articles

Vinorelbine (Navelbine $\left.{ }^{\circledR}\right)$. A New Semisynthetic Vinca Alkaloid*

Krikorian, A., Breillout, $\mathrm{F}$

Ergebnisse der Chirurgie im Rahmen

der multimodalen Therapie des Ösophaguskarzinoms*

Schlag, P 13

Results of Surgery in Multimodality Therapy of Esophageal Cancer*

Schlag, P 13

\section{Originalarbeiten}

Goserelin als Depot GnRH-Analogon zur Therapie prämenopausaler Patientinnen mit metastasiertem Mammakarzinom - 5-Jahres-Erfahrung mit Hormon-Folgetherapien*

Kaufmann, M. , Jonat, W. , Schachner-Wünschmann, E. ,

Bastert, G.,Maass,H

Orale Idarubicintherapie als zytostatische Erstbehandlung bei Patientinnen mit metastasierten

Mammakarzinomen und günstigen Prognosekriterien*

Possinger, K. , Wagner, H. , Worst, P. , Queißer, W. , Bremer, K.

Rieche, K., Klee, M., Westerhausen, M., Donhuijsen-Ant, R.,

Fritze, D., Edler, L., Stiegelbauer, G., Burk, K

31

Phase-II-Studie mit oralem Vinorelbine zur Behandlung des metastasierten Mammakarzinoms*

Queißer, W. , Doss, A. , Wander, H. E. , Bremer, K. , Becher, R.

Rieche, K, Delgado, F.M., Edler, L

-

Zur Therapie des neuropathischen Tumorschmerzes mit Antidepressiva und Antikonvulsiva* Kloke, M.,Höffken, K.,Olbrich,H., Schmidt, C.G 
40

Funktionelle Kriterien für die Stadieneinteilung und Behandlung der Haarzelleukämie* Porzsolt, F., Demeter, J., Heimpel, H 44

Wie kann das krankheitsfreie Überleben von erwachsenen ALL-Patienten mit oder ohne Transplantation miteinander verglichen werden?*

Messerer, D.,Neiß,A., Aydemir, Ü., Hoelzer, D.,Arnold,|R. . 53

Original Paper

The Depot GnRH Analogue Goserelin in the Treatment of Premenopausal Patients with Metastatic Breast Cancer - A five Year Experience and further Endocrine Therapies*

Kaufmann, M., Jonat, W., Schachner-Wünschmann, E.,

Bastert, G., Maass, H 22

Oral Administration of Idarubicin as First Line

Cytostatic Therapy in Patients with Metastasized

Breast Cancer and Favourable Prognosis. A Trial of

the Phase II Study Group of the Association for

Medical Oncology of the German Cancer Society*

Possinger, K., Wagner, H., Worst, P., Queißer, W., Bremer, K.,

Rieche, K., Klee, M., Westerhausen, M., Donhuijsen-Ant, R.,

Fritze, D., Edler, L., Stiegelbauer, G., Burk, K

Phase II Study of Vinorelbine by Oral Route

(in a Hard Gelatine Capsule) for Metastatic Breast

Cancer Patients. A Trial of the Phase I/II Study Group

of the Association for Medical Oncology of the

German Cancer Society*

Queißer, W., Doss, A., Wander, H.E., Bremer, K., Becher, R.,

Rieche, K., Delgado, F.M., Edler, L 35

Anti-Depressants and Anti-Convulsants for the Treatment of Neuropathic Pain Syndromes in

Cancer Patients*

Kloke, M.,Höffken, K.,Olbrich,H., Schmidt, C.G 40

Functional Criteria for Staging and Treatment of Hairy Cell Leukemia*

Porzsolt, F., Demeter, J., Heimpel, H 44

How can Disease-Free Survival

of Adult ALL Patients with or without

Transplants be compared?*

Messerer, D.. Neiß, A., Aydemir, Ü., Hoelzer, D., Arnold, R. . 53

Internationale Zeitschrift fur Krebsforschung und -behandlung

Band 14, Heft 1, Februar 1991

Inhalt

Contents

Operative Therapie bei tumorösem Befall der Wirbelsäule

Venbrocks, R., Donk, R., Hovel, M., Fuhrmann, R.

56

Operative Treatment for Tumorous Lesions of the Spine

Venbrocks, R., Donk, R., Hovel, M.. Fuhrmann, R. 
Zum Stellerrwert von Nachsorgekuren

in der Krankheitsbewältigung von Tumorpatienten

Schmelzle, M., Schwarz, R., Fellhauer, S., Schlag, P

61

The Importance of Inpatient Aftercare within the Coping Process of Cancer Patients

Schmelzle, M., Schwarz, R., Fellhauer, S., Schlag, P. . . .

61

Laufende klinische Studien

Multizentrische prospektive kontrollierte Studie zur Therapie der chronisch myeloischen

Leukämie. Vergleich von Busulfan, Hydroxyurea und Interferon alpha (Stand April 1990)

Hehlmann, R., Heimpel, H., Heinze, B., Georgii, A.,

Kolb, H. J., Hossfeld, D. K., v. Wussow, P., Hochaus. A.,

Grießhammer, M., Diehl, V., Wickramanayake, P. D., Gall-

meier, W. M. , Falge, C. , Essers, U. , Bergmann, L. , Meyer, P. ,

Walther, F, Kanz, L., Queißer, U., Hohnloser, J., Wester-

hausen, M. , Kleeberg, U. R. , Heilein, A. , Käbisch, A. ,

Heiss, F., Zimmermann, R., Meuret, G., Tichelli, A.,

Berdel, W. E., Schmitz, N., Tigges, F.-J., Eimermacher, H.,

Schmid, L., Löffler, H., Pralle, H., Queißer, W., Burkhardt, R.

Ansari, H.,Hasford, J

66

Ongoing Clinical Trials

Prospective Multicenter Study for Treatment of Chronic Myelocytic Leukemia. Comparison of

Busulfan, Hydrocyurea and Interferon alpha (Update April, 1990)

Hehlmann, R., Heimpel, H., Heinze, B.. Georgii, A..

Kolb, H. J., Hossfeld, D. K., v. Wussow, P., Hochaus, A.,

Grießhammer, M., Diehl, V., Wickramanayake. P. D., Gall-

meier, W.M., Falge, C, Essers, U., Bergmann, L., Meyer, P.,

Walther, F., Kanz, L., Queißer, U., Hohnloser, J., Wester-

hausen, M., Kleeberg, U.R., Heilein, A., Käbisch, A.,

Heiss, F., Zimmermann, R., Meuret, G., Tichelli, A.,

Berdel, W. E., Schmitz, N., Tigges, F.-J., Eimermacher, H.,

Schmid, L., Löffler, H., Pralle, H., Queißer, W. , Burkhardt. R.

Ansari, H., Hasford, J

66

Kurzmitteilungen

Eine neue Methode zur mehrfachen Injektion von Zytostatika bei Ratten*

Klesper, B., Zywietz, F

74

Short Communications

A New Method for Multiple Applications of Cytostatic Drugs in Rats*

Klesper, B., Zywietz, F 
Kongreßmitteilungen

Abstracts des Symposiums der Phase I/II

Studiengruppe der Arbeitsgemeinschaft

für Internistische Onkologie (AIO)

der Deutschen Krebsgesellschaft $\quad 76$

Mitteilungen onkologischer Gesellschaften

AIO-Mitteilungen $\quad 84$

Impressum 1

Inhaltsverzeichnis 2

Industrieforum $\quad 89$

Hinweise für Autoren $\quad 90$

Congress Reports

Abstracts of the Symposium of the Phase I/II

Study Group of the Arbeitsgemeinschaft

für Internistische Onkologie (AIO)

of the German Cancer Society

76

Reports of Oncological Societies

AIO-Reports 84

Imprint

1

Contents 2

Industrial Forum

89

Instructions to Authors

90

diese Arbeit erscheint in englischer Sprache

this article is printed in English

Bibliographischer Hinweis: Inhaltsverzeichnisse dieser Zeitschrift erscheinen regelmäßig in current contents ${ }^{\circledR}$ sowie in anderen bibliographischen Diensten. 